\title{
KSIĄŻKI NADESŁANE DO REDAKCJI
}

1. Bartinik Czesław ks., Chrześcijańska nauka o narodzie wedtug prymasa Stefana Wyszyńskiego. Lublin 1981, KUL, s. 21, zł 25

2. Bazylak Józef ks., Sieg Stanisław, Elementy higieny psychicznej $w$ psychologii pastoralnej. W-wa 1983, ATK, s. 296, zł 300

3. Działa Emanuel OP, W milczeniu $i$ nadziei. Poznań 1982, „W drodze", s. 322

4. Filipiak Marian ks., Człowiek wspólczesny a Stary Testament. Lublin 1982, KUL, s. 190, zł 150

5. Jaroszewicz Jan bp, „Badźcie doskonali”. Rozważania dla zakonnic. W-wa 1981, ATK, s. 618, zł 420

6. K a mieńska Anna, Notatnik 1965-1972. Poznań 1982, „W drodze”, s. 316

7. Kościół katolicki na ziemiach Polski w czasie drugiej wojny światowej t. XII: Stopniak Franciszek ks., Polskie swiatynie katolickie podczas drugiej wojny światowej. W-wa 1982, ATK, s. 281

8. M a 1 iński Mieczysław kis., Jest taki kwiat. W-wa 1982, Wyd. Sióstr Loretanek, s. 233

9. Opera philosophorum Medii Aevi - Textus et studia:

t. V, z. 1 i 2: S e ńk o Władysław, Repertorium commentariorum Medii Aevi in Aristotelem latinorum quae in bibliothecis publicis Parisiis asservantur. W-wa 1982, ATK, s. $231+248$

10. Praca zbiorowa, Napetnieni Duchem Swiętym. Poznań 1982, „W drodze", s. 202

11. Praca z biorowa, Perspektywy i problemy teologii moralnej. Przel. Tadeusz Mieszkowski. W-wa 1982, PAX, s. 332, zł 350

12. R om a niuk Kazimierz bp, Nowy Testament bez problemów. W-wa 1983 , s. 221 , zł 400

13. S c hn a cken burg Rudolf, Nauka moralna Nowego Testamentu. Przeł. Franciszek Dylewski. W-wa 1983, PAX, s. 361, zł 200

14. Stryjkowski Julian, Odpowiedź. Poznań 1982, „W drodze” s. 115

15. Studia ekumeniczne, t. I, pod red. ks. J. Myśkowa. W-wa 1982, ATK, s. 338

16. Studia teologiczne,

t. III: Praca z biorowa, Obraz Boga $w$ Psalterzu, pod red. ks. A. Eckmanna, ks. St. Eacha i ks. A. Troniny. Lublin 1982, KUL, s. 178, zł 150

17. Wor oniecki Jacek OP, Pełnia modlitwy. Poznań 1982, „W drodze”, S. 195

18. W y socki Józef ks., Rytuał rodzinny (Aby rodzina byla bardziej Kościołem), Olsztyn 1981, Warm. Wyd. Diecezjalne, s. 314, zl 200

19. ¿̇ mu da Ryszard, Bibliografia historii Kościola w Polsce za lata 19751977, cz. I i II. W-wa 1982, ATK, s. $415+418$ 